\title{
The Volume Activated Potassium Channel KCNK5 is Up-Regulated in Activated Human T Cells, but Volume Regulation is Impaired
}

\author{
Signe S. Kirkegaard ${ }^{\mathrm{a}}$ Pernille Dyhl Strøm ${ }^{\mathrm{a}}$ Steen Gammeltoft ${ }^{\mathrm{b}} \quad$ Anker Jon Hansen $^{\mathrm{c}}$ \\ Else K. Hoffmann ${ }^{\mathrm{a}}$ \\ aSection for Cell and Developmental Biology, University of Copenhagen, Copenhagen, ${ }^{\mathrm{b} D e p a r t m e n t}$ of \\ Clinical Biochemistry, Glostrup Hospital, Glostrup, 'Novo Nordisk, Måløv, Denmark
}

\section{Key Words}

$\mathrm{KCNK5} \cdot \mathrm{T}$ cell activation $\cdot \mathrm{CD} 3 / \mathrm{CD} 28 \cdot \mathrm{T}$ cells $\bullet$ RVD

\begin{abstract}
Background/Aims: The potential role of the two-pore domain potassium channel KCNK5 (also known as TASK-2 and $\mathrm{K}_{2 \mathrm{p}} 5.1$ ) in activated T cell physiology has only recently been described. So far KCNK5 has been described to be up-regulated in T cells in multiple sclerosis patients and to be implicated in the volume regulatory mechanism regulatory volume decrease (RVD) in T cells. Methods: We investigated the time-dependent expression pattern of KCNK5 in CD3/ CD28 activated human T cells using qPCR and Western blotting and its role in RVD using a Coulter Counter. Results: KCNK5 is highly up-regulated in CD3/CD28 activated T cells both at mRNA (after $24 \mathrm{~h}$ ) and protein level (72 and $144 \mathrm{~h}$ ), but despite this up-regulation the RVD response is inhibited. Furthermore, the swelling-activated $\mathrm{Cl}^{-}$permeability in activated $\mathrm{T}$ cells is strongly decreased, and the RVD inhibition is predominantly due to the decreased $\mathrm{Cl}^{-}$ permeability. Conclusion: The up-regulated KCNK5 in activated human T cells does not play a volume regulatory role, due to decreased $\mathrm{Cl}^{-}$permeability. We speculate that the KCNK5 upregulation might play a role in hyperpolarization of the cell membrane leading to increased $\mathrm{Ca}^{2+}$ influx and proliferation of $\mathrm{T}$ cells.
\end{abstract}

Copyright @ 2016 S. Karger AG, Basel

\section{Introduction}

Ion channels are important for $\mathrm{T}$ cell activation and activated $\mathrm{T}$ cell function. Especially the role of the voltage-gated $\mathrm{Kv} 1.3$, the $\mathrm{Ca}^{2+}$-activated $\mathrm{KCa} 3.1$ and $\mathrm{Ca}^{2+}$ release-activated $\mathrm{Ca}^{2+}$ (CRAC) channel is well known. For reviews on ion channels and T cells see [1-3]. Activation of $\mathrm{T}$ cells when encountering an antigen requires a sustained increase in intracellular $\mathrm{Ca}^{2+}$

Else K. Hoffmann, PhD

KARGER
Section for Cell and Developmental Biology, Department of Biology, The August Krogh Building, University of Copenhagen, 13, Universitetsparken, DK-2100, Copenhagen, (Denmark); E-Mail ekhoffmann@bio.ku.dk 
concentration $\left(\left[\mathrm{Ca}^{2+}\right]_{\mathrm{i}}\right)$ which is generated by $\mathrm{IP}_{3}$ mediated $\mathrm{Ca}^{2+}$ release from stores in the ER which in turn mediates the activation of CRAC channels allowing $\mathrm{Ca}^{2+}$ entry from the extracellular medium. This $\mathrm{Ca}^{2+}$ influx and subsequent rise in $\left[\mathrm{Ca}^{2+}\right]_{\mathrm{i}}$ activates $\mathrm{KCa} 1.3$ and also causes a depolarization activating the voltage sensitive $\mathrm{Kv} 1.3 \mathrm{~K}^{+}$channel. Activation of Kv1.3 and KCa3.1 causes $\mathrm{K}^{+}$efflux and hyperpolarization of the plasma membrane allowing further $\mathrm{Ca}^{2+}$ entry via the CRAC channels in the membrane.

The sustained increase in $\left[\mathrm{Ca}^{2+}\right]_{\mathrm{i}}$ is essential for the transcription and expression of interleukin 2 (IL-2) which in turn is vital in keeping the T cells activated without the requirement of further antigen stimulation (see [4]). Other ion channels, however, have been implicated in T cell activation. The leak conductance channel (TREK-2) was described in WEHI-231 cells which is a murine immature B cell line $[5,6]$. Further studies have also revealed the presence of two-pore domain $\mathrm{K}^{+}$channels in lymphocytes e.g. TASK-1, 2 (KCNK5) and 3 [7]. Of special interest to this study Bittner and co-workers suggested that the two-pore domain potassium channel KCNK5 (also known as TASK-2 or $\mathrm{K}_{2 \mathrm{P}} 5.1$ ) has a role in $\mathrm{T}$ cell activation and in multiple sclerosis [8].

T cells are in constant movement around the body and thereby subjected to extracellular osmotic changes e.g. in the kidney. T cells are, as most other mammalian cells, capable of performing RVD (regulatory volume decrease) in response to cell swelling [9-12].

KCNK5 has previously been shown to be volume sensitive and to be implicated in the volume regulatory process of RVD in response to cell swelling in various cell types and tissues including Ehrlich Ascites Tumor (EAT) cells [13, 14], mouse proximal tubules [15], human and murine spermatozoa [16,17] and murine [18] and human T lymphocytes (1). For a recent review on KCNK5 see [19]. Other types of $\mathrm{K}^{+}$channels have been suggested to play a part in T cell volume regulation including Kv1.3 [20, 21] and KCa3.1 [22]. However, volume regulation also requires the transport of anions, which includes the volume regulated anion channel (VRAC) responsible for the swelling-activated $\mathrm{Cl}^{-}$current [2].

KCNK5 is up-regulated during T cell activation $[8,23]$ but there is, to our knowledge, no description of the time dependency of the expression pattern of KCNK5 during T cell activation and its physiological consequences. This is the subject of the present paper, and in addition we demonstrate a strong decrease in the swelling-activated $\mathrm{Cl}^{-}$permeability during the activation, which inhibits the RVD process in the large activated T cells.

\section{Materials and Methods}

Solution and Materials

Volume measurements: Hypotonic Ringer's solution (160 mOsm) contained (in mM): $71.5 \mathrm{NaCl}, 2.5 \mathrm{KCl}$, $0.5 \mathrm{MgSO}_{4}, 0.5 \mathrm{Na}_{2} \mathrm{HPO}_{4}, 0.5 \mathrm{CaCl}_{2}, 3.3 \mathrm{MOPS}, 3.3 \mathrm{TES}$ and 5 HEPES, pH 7.4. Isotonic Ringer's solution (300 mOsm) was obtained by addition of sucrose. $\mathrm{Cl}^{-}$permeability: the hypotonic (150 mOsm) low $\mathrm{Na}^{+} \mathrm{Ringer}^{\prime} \mathrm{S}$ solution contained (in mM): $70 \mathrm{NMDG}$ (N-methyl-D-glucamine) $\mathrm{Cl}-0.8 \mathrm{NaCl}, 5 \mathrm{KCl}, 1 \mathrm{~K}_{2} \mathrm{HPO}_{4}, 1 \mathrm{MgSO}_{4}, 1$ $\mathrm{CaCl}_{2}, 3.3$ MOPS, 3.3 TES and 5 HEPES, pH 7.4.

Gramicidin and Clofilium was purchased from Sigma and used in the concentrations $1 \mu \mathrm{M}$ and $100 \mu \mathrm{M}$ respectively

\section{Purification and maintenance of cells}

Human T cells were purified from buffy coats from healthy donors. Human buffy coats were obtained from the blood bank at Rigshospitalet, Copenhagen, Denmark. All procedures were performed at room temperature. The T cell population, CD4 and CD8 subtypes were purified from buffy coats using RosetteSep ${ }^{\mathrm{TM}}$ (Human T Cell Enrichment Cocktail, Human CD4+ T Cell Enrichment Cocktail and Human CD8 T Cell Enrichment Cocktail all from StemCell Tech.) according to manufactures description. After purification any residual red blood cells was lysed using RBC lysis buffer (eBioscience). Purified T cells, CD4 or CD8 subtypes

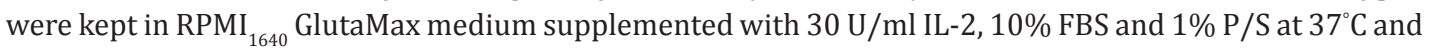
$5 \% \mathrm{CO}_{2}$.

\section{KARGER}




\section{Cellular Physiology Cell Physiol Biochem 2016;38:883-892 \\ \begin{tabular}{l|l|l} 
DOI: 10.1159/000443042 & (C) 2016 S. Karger AG, Basel
\end{tabular} \\ and Biochemistry Published online: February 25, $2016 \quad$ www.karger.com/cpb \\ Kirkegaard et al.: KCNK5 and T Cell Activation}

\section{RNA purification and $q P C R$}

T cells were stimulated for 2, 4, 8, 12, 24, 48, 72 and 144 hours with CD3/CD28 beads (Invitrogen) in the ratio 1:1 (according to manufactures instruction) and RNA was purified from lysates using NucleoSpin ${ }^{\circledR}$ RNA II (Macherey-Nagel) according to manufacturer's instructions. Reverse transcriptase PCR with SuperScript II (Invitrogen) and oligo(dT) ${ }_{12-18}$ primer (Invitrogen) was used to generate cDNA from the purified mRNA and performed on a Eppendorf Mastercycler as previously described [24]. QPCR was performed using a Stratagene MX4000 real-time PCR system, Brilliant ${ }^{\circledR}$ II SYBR ${ }^{\circledR}$ Green QPCR Master Mix (Stratagene, Agilent Technologies) and the following primers: hKCNK5 forward: 5'-ACCACCCACTCATCTTCCAG-3', hKCNK5 reverse: 5'-AGTGCTGGTGAAGGTGGACT-3', hKv1.3 forward: 5'-CACTTCAGGTTTCAGCAGCA-3', hKv1.3 reverse: 5'-TGTCTCCCGGTGGTAGAAGT-3', hKCa3.1 forward: 5'-ACTGGGCACCTTTCAGACAC-3' and KCa3.1 reverse: 5'-ACGTGCTTCTCTGCCTTGTT-3'. A total volume of $20 \mu \mathrm{l}$ containing $1 \mu \mathrm{l}$ of the cDNA, $200 \mathrm{nM}$ of primers, and $10 \mu \mathrm{l} 2 \times$ MasterMix was used.

Despite testing numerous potential reference genes none of them lived up to our standards and instead determination of total cDNA concentration was used to correct the data obtained. To determine cDNA content upon PCR reaction and to normalize samples, Quant-iT ${ }^{\text {тм }}$ OliGreen ${ }^{\circledR}$ SsDNA Assay Kit was used as described in [25]. Standard curves were also done to measure primer efficiency which was corrected for in calculations. Primers were selected using Primer3 software and purchased from MWG Eurofins (Germany). Quantification was carried out using the Pfaffl method [26].

\section{Western blotting}

T cells were stimulated for $2 \mathrm{~h}, 4 \mathrm{~h}, 8 \mathrm{~h}, 12 \mathrm{~h}, 24 \mathrm{~h}, 48 \mathrm{~h}, 72 \mathrm{~h}$ or $144 \mathrm{~h}$ days with CD3/CD28 beads and lysed in $95^{\circ} \mathrm{C}$ lysis buffer (10 mM Tris- $\mathrm{HCl} \mathrm{pH} \mathrm{7.4,1 \%} \mathrm{SDS,} 20 \mathrm{mM}$ EDTA) with protease inhibitors (Roche Applied Science) and phosphatase inhibitors added. SDS-PAGE and Western blotting was performed as previously described [13], where protein concentration measurements assured that an equal amount of protein was loaded into every well. We used the following antibodies and concentrations: KCNK5 (TASK-2) (Alomone Lab., Israel) 1:100, $\beta$-actin (Sigma-Aldrich) 1:1000.

\section{Volume measurements by Coulter Counter}

Volume measurements: T cells were stimulated with CD3/CD28 beads for 2, 4, 8, 12, 24, 48, 72 or 144 hours before the absolute cell volume was measured by electronic cell sizing using the Coulter Multisizer ll (Coulter, Luton, UK) with a tube orifice of $70 \mu \mathrm{m}$. Before measurements calibration was performed using 15 $\mu \mathrm{m}$ latex beads. Approximately $2.5 \times 10^{6}$ cells were used per experiment and cell volume was determined in either isotonic or hypotonic Ringer's solutions (all micro-filtered before use). Volume recovery was estimated in two different ways, by \% recovery after $3 \mathrm{~min}$. as previously described [13] and by calculating the initial rate of RVD measured as the slope of the recovery part of the RVD curve.

$\mathrm{Cl}^{-}$permeability: to determine if the $\mathrm{Cl}^{-}$permeability was decreased in activated $\mathrm{T}$ cells we used a method previously described in [27] with some minor alterations. Cell volume regulation (i.e. RVD) requires efflux of both cations and anions. We employed Clofilium as a blocker of potassium channel KCNK5 and substituted most of sodium with NMDG in the Ringer's solution (see above), this was done in order to obtain equilibrium for $\mathrm{Na}^{+}$, thus ensuring no net movement. The principle of the experiments is as follows: Clofilium blocks the KCNK5 channel and hence RVD. When Gramicidin is added high cation permeability is introduced making $\mathrm{Cl}^{-}$the limiting factor. The procedure makes it possible to assess the relative $\mathrm{Cl}^{-}$ permeability.

\section{Statistical methods}

Statistical significance was determined by Student's T-test or one-way analysis of variance (ANOVA) where one star represent statistical significance at a 95\% level, two stars at a 99\% level and three stars at a > 99\% significance level.

\section{Results}

KCNK5 and $K_{C a} 3.1$ mRNA's are up-regulated in activated $T$ cells

Activation of T cells for 2, 4, 8, 12, 24, 48, 72 or 144 hours with CD3/CD28 beads caused up-regulation of KCa3.1 mRNA (Fig. 1A) after $72 \mathrm{~h}$ and $144 \mathrm{~h}$ (ANOVA) as well as KCNK5 


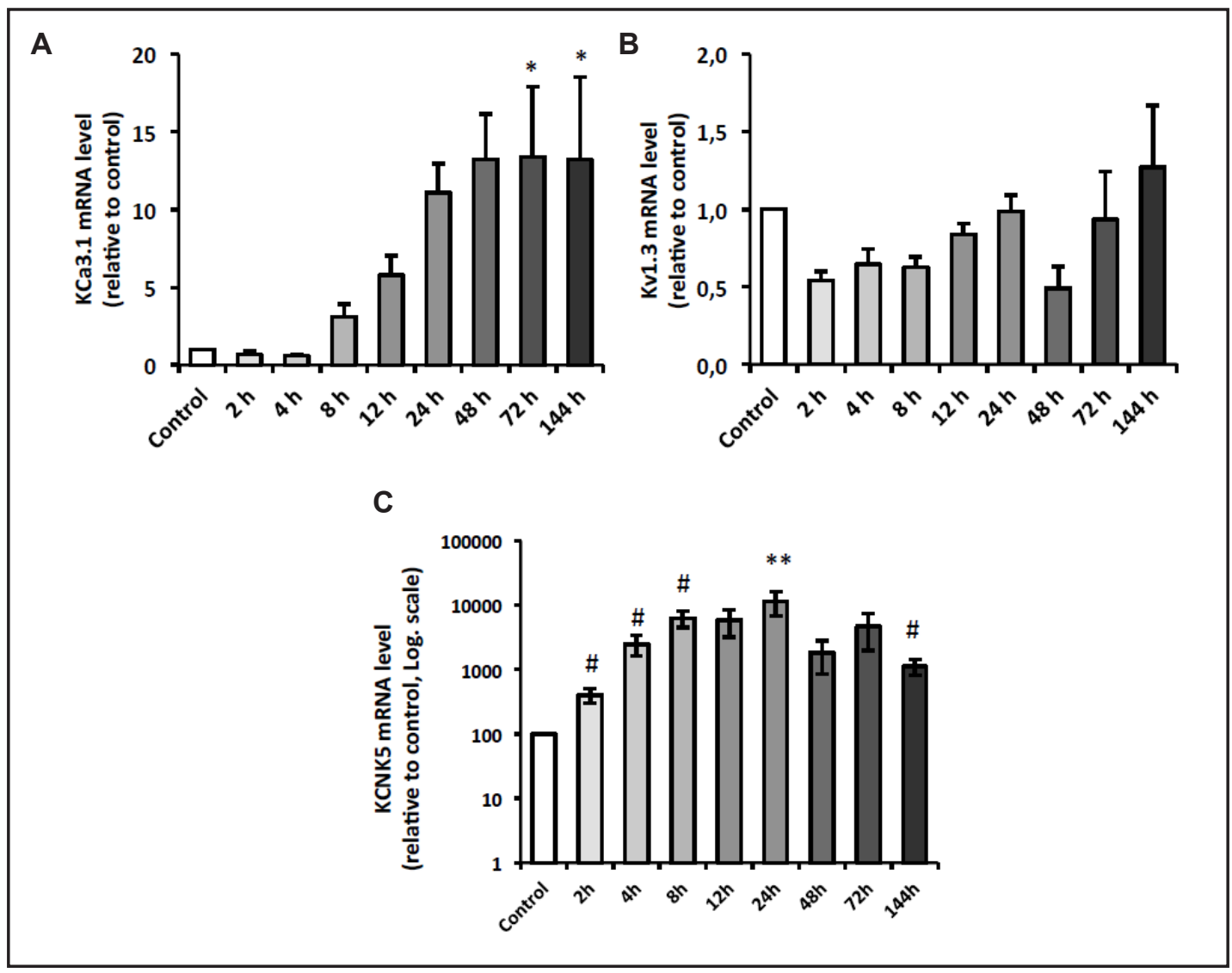

Fig. 1. mRNA levels of KCNK5, KCa3.1 and Kv1.3 determined by qPCR. T cells were purified from human buffy coats and stimulated with CD3/CD28 activation beads for $2 \mathrm{~h}, 4 \mathrm{~h}, 8 \mathrm{~h}, 12 \mathrm{~h}, 24 \mathrm{~h}, 48 \mathrm{~h}, 72 \mathrm{~h}$ or $144 \mathrm{~h}$. mRNA levels were determined using qPCR and primers against KCa3.1 (A), Kv1.3 (B) and KCNK5 (C). ANOVA $\left.{ }^{*}\right)$ and student's t-test (\#) was used to test for statistical significance on 5-8 independent experiments $(\mathrm{n}=$ 2 for 48 h). One star (*) or \# indicates a 95\% significance level and two stars indicate significance at a 99\% level.

mRNA after 2 (student's t-test), 4 (student's t-test), 8 (student's t-test), 24 (ANOVA) and 144 $\mathrm{h}$ (student's t-test) (Fig. 1C) while no significant change was seen in regard to Kv1.3 (Fig. 1B). A tendency to initial down-regulation of KCa3.1 (Fig. 1A) mRNA level was observed upon 2 and $4 \mathrm{~h}$ of stimulation followed by a tendency to increasing up-regulation after 8,12 and $24 \mathrm{~h}$ reaching a significant level of a 13 fold up-regulation after 72 h. KCNK5 (Fig. 1C) showed the largest up-regulation of the three potassium channels studied with a 115 fold peak-increase in mRNA level after $24 \mathrm{~h}$ of activation. There was no initial down-regulation thus a significant (T-test) 4 fold increase was already seen after $2 \mathrm{~h}$ of CD3/CD28 stimulation.

\section{KCNK5 protein is up-regulated in activated T cells}

When measuring KCNK5 protein levels a biphasic protein expression pattern during activation with CD3/CD28 beads (Fig. 2A) was seen. There was an initial significant decrease ( $\mathrm{p}<0.001$, student's t-test) at 2 and $4 \mathrm{~h}$ followed by a tendency to increasing protein expression after $8,12,24$ and $48 \mathrm{~h}$ (though not statistically significant) peaking at $72 \mathrm{~h}$ with a significant $277 \%$ (ANOVA) increase compared to non-stimulated cells. A subsequent slight decrease of KCNK5 protein expression to $209 \%$ at $144 \mathrm{~h}$ was furthermore seen compared to the quiescent control cells. The activation of $\mathrm{T}$ cells stimulated proliferation causing a more than three-fold increase upon $72 \mathrm{~h}$ of CD3/CD28 stimulation compared to non-stimulated control cells (two experiments, data not shown). When comparing the up-regulation of the 


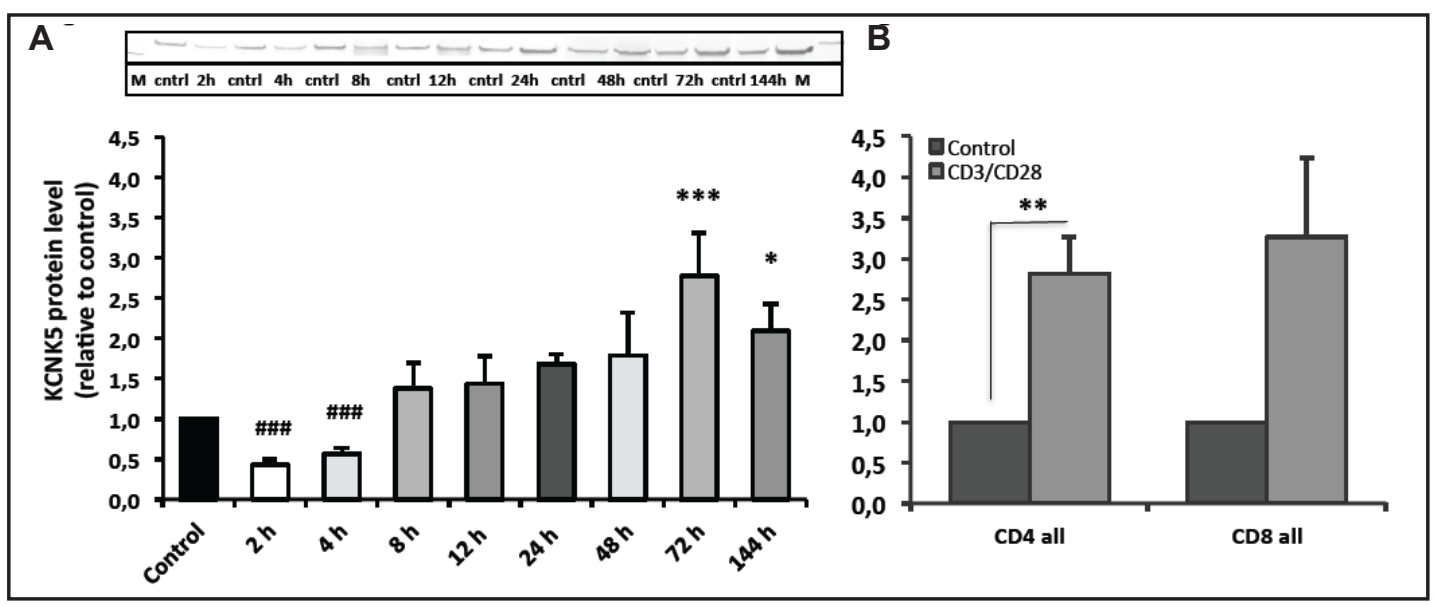

Fig. 2. KCNK5 protein expression. T cells whole population (Fig. 2A) and CD4 and CD (subtypes) (Fig. 2B) were purified from human buffy coats and stimulated with CD3/CD28 activation beads (CD4 and CD8 subtypes were only stimulated for $144 \mathrm{~h}$ ) for $2 \mathrm{~h}, 4 \mathrm{~h}, 8 \mathrm{~h}, 12 \mathrm{~h}, 24 \mathrm{~h}, 48 \mathrm{~h}, 72 \mathrm{~h}$ or $144 \mathrm{~h}$. SDS-PAGE and Western blotting was performed using antibodies against KCNK5 and $\beta$-actin. Protein bands were visualized and pixel density calculated. ANOVA $\left({ }^{*}\right)$ or student's t-test (\#) was used to determine statistical significance on 3-10 independent experiments and one star $\left(^{*}\right)$ represents a statistical significance level of $95 \%$ whereas $\left({ }^{* * *}\right)$ indicate a significance level $>99 \%$. (Fig. 2A) No significance was seen after 2 and $4 \mathrm{~h}$ using the statistical test ANOVA but when using Student's T-test both times showed significance here represented by (\#\#\#) indicating a level of significance of $>99 \%$. (Fig. 2B) Stimulation with CD3/CD28 beads for 3 days increased KCNK5 protein expression in both CD4 and CD8 subtypes, but no significant difference in KCNK5 expression was observed between the two $\mathrm{T}$ cell subtypes.

two T-cell subtypes CD4 and CD8 (stimulated for $144 \mathrm{~h}$ ) no significant difference in KCNK5 protein expression level was observed (Fig. 2B).

$T$ cell activation causes increased cell volume, decreased RVD ability and increased hypotonic swelling

Since the KCNK5 channel is a known volume regulator we tested the ability of activated $\mathrm{T}$ cells to perform regulatory volume decrease (RVD). The volume measurements depicted in Fig. 3 (relative values) and table 1 (absolute values) show the well-known fact that activated $\mathrm{T}$ cells become larger (Fig. $3 \mathrm{~A}+\mathrm{B}$ and Table 1 ). After $8 \mathrm{~h}$ of CD3/CD28 stimulation T cells in isotonic Ringer's solution began increasing their volume and after $24 \mathrm{~h}$ the mean volume was significantly $(\mathrm{p}<0.001)$ larger than the control cells with a mean volume of $172 \mu \mathrm{m}^{3}$ compared to $119 \mu \mathrm{m}^{3}$ of the control cells (Table 1). There was a subsequent increase of cell volume to more than $200 \%$ at 72 and $144 \mathrm{~h}$ (Fig. 3B).

Figure 3A shows the time course of the cell volume of activated (144 h) and nonactivated cells when exposed to a hypotonic Ringer's solution. CD3/CD28 stimulated T cells had increased maximum swelling which was significant after $24 \mathrm{~h}$, with highest measured values after $72 \mathrm{~h}$ and a small decrease seen after $144 \mathrm{~h}$. At $72 \mathrm{~h}$ their maximum swelling reached a value of $309 \mu \mathrm{m}^{3}$ compared to a gain of volume of $72 \mu \mathrm{m}^{3}$ seen in control cells equivalent to a 4 times increase of cell volume (Fig. 3C and Table 1). Maximum swelling values upon 24,72 and $144 \mathrm{~h}$ of stimulation was significantly larger than control values $(\mathrm{p}<$ 0.001 ) both in absolute values and in relative terms (Fig. $3 \mathrm{C}$ and Table 1).

Besides a more pronounced swelling when hypotonically challenged, activated $\mathrm{T}$ cells showed an impaired RVD performance compared to control cells. Fig. 3A shows that both activated and non-activated T cells swelled and performed RVD. However, \% recovery after 3 min. [13] and the initial rate of RVD was much less in stimulated T cells than in control cells (Fig. 3D+E respectively). The RVD response or the recovery percentages of non-activated T cells was not significantly different from each other at the measured time-points (average recovery of $36 \%$ after $3 \mathrm{~min}$ ). Fig. 3D and Table 1 illustrates that the RVD of activated T cells 


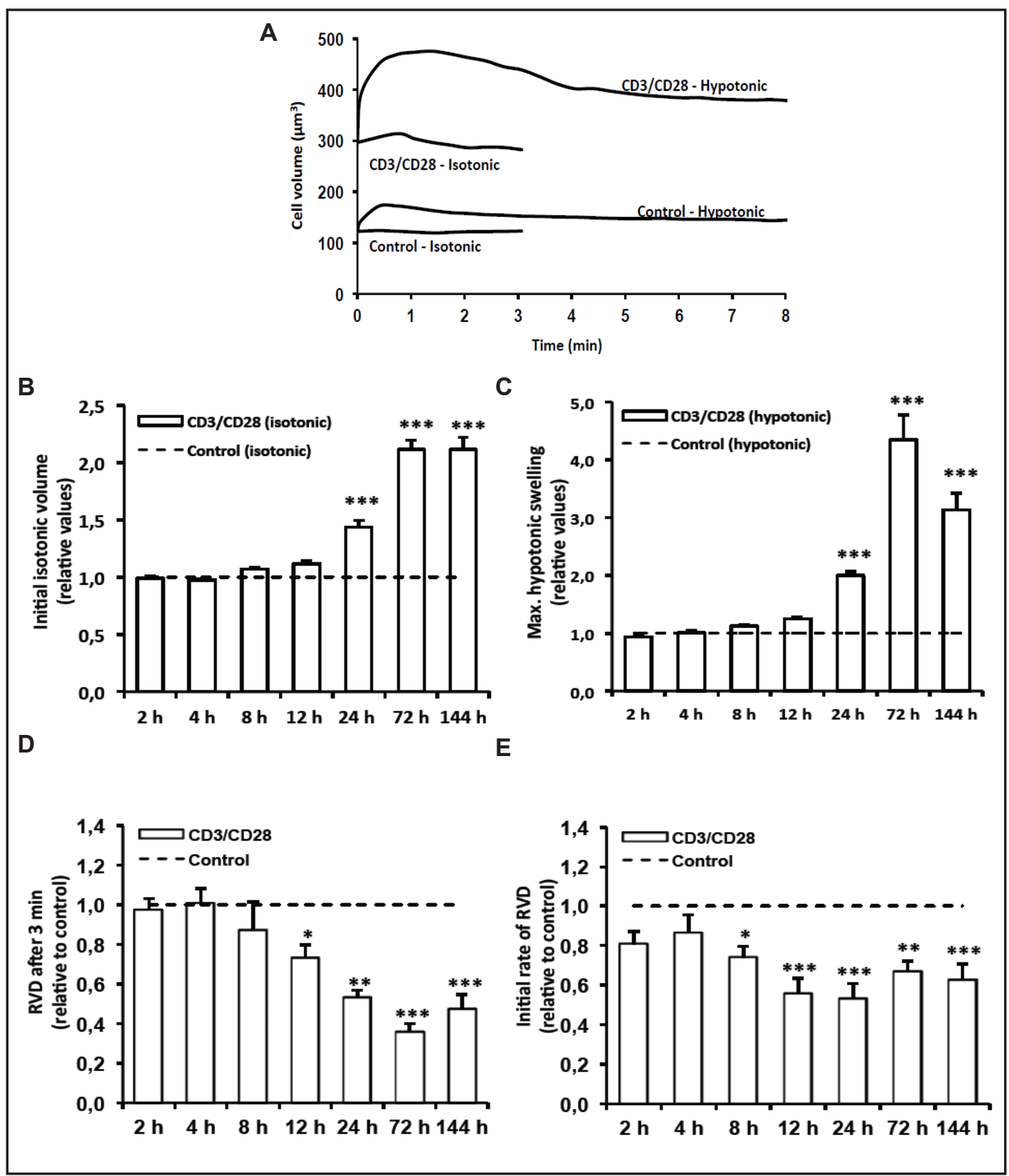

Fig. 3. RVD in CD3/CD28 stimulated T cells and non-activated controls. T cells were purified from human buffy coats and stimulated with CD3/CD28 activation beads for 2, 4, 8, 12, 24, 72 or 144 hours before absolute volume was measured using a coulter counter. Stimulated T cells and non-stimulated controls were measured in either isotonic (300 mOsm) or hypotonic (160 m0sm) Ringer's solution. (A) representative figure showing RVD over time ( $\mathrm{min}$ ) for untreated control cells and CD3/CD28 stimulated T cells (144 hours). (B) Initial mean volume measured in isotonic Ringer's solution (C) Mean maximal swelling seen in hypotonic Ringer's solution determined as $V_{\max }-V_{\text {iso }}$ where $V_{\max }$ is the maximal swelling seen when subjecting the cells to hypotonicity and $V_{\text {iso }}$ is the volume seen in isotonic Ringer's solution. (D) Mean volume recovery after 3 min was calculated as $\left(\mathrm{V}_{\max }-\mathrm{V}_{3 \min }\right) /\left(\mathrm{V}_{\text {max }}-\mathrm{V}_{\text {iso }}\right)$, where $\mathrm{V}_{\text {max }}, \mathrm{V}_{3 \min }$ and $\mathrm{V}_{\text {iso }}$ are the maximal cell volume, cell volume at time $3 \mathrm{~min}$ and cell volume under isotonic conditions, respectively. (E) initial rate of RVD (the slope) was calculated using linear regression on the linear part of the RVD curve, from maximum volume to the end of linearity. ANOVA test was used to test for statistical significance on 5-7 independent experiments and one star $\left({ }^{*}\right)$ represent a 95\% significance level whereas two $\left({ }^{* *}\right)$ and three stars $\left(^{* * *}\right)$ indicate significance levels of $99 \%$ and $>99 \%$ respectively. 


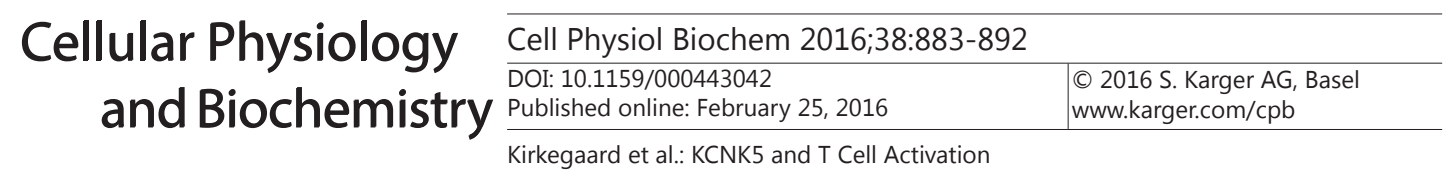

Table 1. Volume measurements in absolute values. Mean values of isotonic initial volume, max. swelling upon hypotonicity, \% recovery and initial rate of RVD \pm SD showed in absolute values (Fig. 3 shows the same results in relative values)

\begin{tabular}{|c|c|c|c|c|c|c|c|c|}
\hline \multicolumn{9}{|c|}{ Volume measurements in absolute values } \\
\hline & \multicolumn{2}{|c|}{$\begin{array}{l}\text { Initial volume (iso) } \\
\qquad\left(\mu \mathrm{m}^{3}\right)\end{array}$} & \multicolumn{2}{|c|}{$\begin{array}{c}\text { Max. swelling (hypo) } \\
\left(\mu \mathrm{m}^{3}\right)\end{array}$} & \multicolumn{2}{|c|}{$\begin{array}{l}\text { RVD } \\
(\%)\end{array}$} & \multicolumn{2}{|c|}{ Initial rate of RVD $\mu \mathrm{m}^{3} / \mathrm{sec}$} \\
\hline & Control & $\mathrm{CD} 3 / \mathrm{CD} 28$ & Control & $\mathrm{CD} 3 / \mathrm{CD} 28$ & Control & $\mathrm{CD} 3 / \mathrm{CD} 28$ & Control & $\mathrm{CD} 3 / \mathrm{CD} 28$ \\
\hline $2 \mathrm{~h}$ & $122.7 \pm 8.69$ & $122.6 \pm 10.5$ & $68 \pm 8.69$ & $60.9 \pm 13.5$ & $38.96 \pm 6.09$ & $37.93 \pm 8.11$ & $-0.0025 \pm 5.7 \mathrm{e}^{-4}$ & $-0.002 \pm 6 \mathrm{e}^{-4}$ \\
\hline $4 \mathrm{~h}$ & $117.5 \pm 9.51$ & $114.8 \pm 11.3$ & $69.3 \pm 11.5$ & $69.4 \pm 9.66$ & $33.68 \pm 7.12$ & $34.38 \pm 11.44$ & $-0.0024 \pm 5 \mathrm{e}^{-4}$ & $-0.0021 \pm 6.9 \mathrm{e}^{-4}$ \\
\hline $8 \mathrm{~h}$ & $115.1 \pm 9.61$ & $123.1 \pm 11.5$ & $72.7 \pm 10.3$ & $81.1 \pm 7.57$ & $33.92 \pm 6.88$ & $28.35 \pm 10.62$ & $-0.0025 \pm 4 \mathrm{e}^{-4}$ & $-0.0018 \pm 1.8 \mathrm{e}^{-4}$ \\
\hline $12 \mathrm{~h}$ & $114.1 \pm 9.44$ & $127.5 \pm 14.3$ & $71.7 \pm 12.1$ & $89.2 \pm 12$ & $36.27 \pm 6.47$ & $26.5 \pm 7$ & $-0.0028 \pm 6 \mathrm{e}^{-4}$ & $-0.0015 \pm 3.5 e^{-4}$ \\
\hline $24 \mathrm{~h}$ & $118.8 \pm 10.9$ & $171.6 \pm 29.6$ & $63.9 \pm 11.6$ & $127.5 \pm 24$ & $40.68 \pm 5.07$ & $21.85 \pm 5.64$ & $-0.0028 \pm 4.3 \mathrm{e}^{-4}$ & $-0.0015 \pm 4.7 \mathrm{e}^{-4}$ \\
\hline $72 \mathrm{~h}$ & $110.8 \pm 7.32$ & $237.9 \pm 15.5$ & $71.9 \pm 15.1$ & $309.3 \pm 34$ & $35.7 \pm 5.67$ & $13.61 \pm 4.82$ & $-0.0027 \pm 3.9 \mathrm{e}^{-4}$ & $-0.0019 \pm 3.4 \mathrm{e}^{-4}$ \\
\hline $144 \mathrm{~h}$ & $112.4 \pm 6.47$ & $237.6 \pm 34.1$ & $69.2 \pm 13.8$ & $209.4 \pm 28.7$ & $32.99 \pm 6.6$ & $15.52 \pm 5.82$ & $-0.0025 \pm 4.1 e^{-4}$ & $-0.0016 \pm 6 e^{-4}$ \\
\hline
\end{tabular}

Fig. 4. $\mathrm{Cl}^{-}$permeability in RVD in $\mathrm{CD} 3 / \mathrm{CD} 28$ activated and non-activated T cells. T cells were purified from human buffy coats and stimulated with CD3/ CD28 beads for 72 hours. Activated T cells and nonactivated control cells were treated with $100 \mu \mathrm{M}$ Clofilium for 30 min to block the potassium channels. The cells were swollen in hypotonic low $\mathrm{Na}^{+} \mathrm{NMDG}$ Ringer's solution and their volume was measured using a Coulter Counter. After one min. $1 \mu \mathrm{M}$ Gramicidin was added to facilitate cation flux thereby letting the $\mathrm{Cl}^{-}$flux being the limiting factor. The figure shows \% recovery after 5 min of activated and nonactivated T cells treated with Clofilium and Gramicidin. Student's T-test was used to test for statistical significance on 3 independent experiments and two stars ${ }^{* *}$ ) indicate a significance level of $99 \%$.

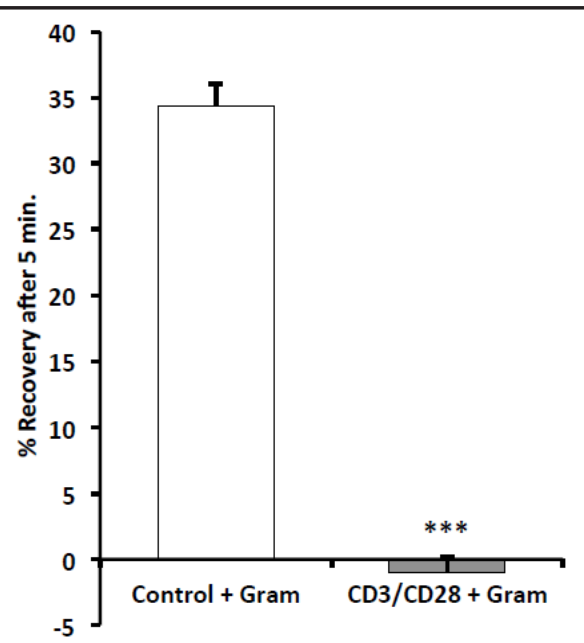

started to decrease after $8 \mathrm{~h}$ followed by significant decreases at $12,24,72$ and $144 \mathrm{~h}$ of stimulation. After $72 \mathrm{~h}$ of CD3/CD28 stimulation the cells had the lowest ability to perform RVD with a recovery of $13.6 \%$ compared to $35.7 \%$ (Table 1 ) of the non-stimulated cells and equivalent to a $60 \%$ decrease (Fig. 3D). When measuring RVD by the initial rate of shrinkage the results was similar - activated T cells have a lesser RVD performance than control cells (Fig. 3E and Table 1). The initial rate of RVD was faster in all controls when compared to the activated T cells though the values was only significantly lower after 8, 12, 24, 72 and $144 \mathrm{~h}$.

\section{Cl permeability of activated T cells is inhibited}

The considerable up-regulation of KCNK5 in activated T cells does not increase their ability to perform RVD. On the contrary RVD is diminished in CD3/CD28 activated cells. Since RVD is driven by the extrusion of $\mathrm{KCl}$ we speculated if the $\mathrm{Cl}^{-}$permeability of the activated cells could be decreased. As described in materials and methods and in [27] we used the rate of RVD after addition of Gramicidin in a low $\mathrm{Na}^{+}$medium with Clofilium to block the $\mathrm{K}^{+}$ channel as a measure of the swelling-activated $\mathrm{Cl}^{-}$permeability. As seen in Fig. 4 the addition of Gramicidin to hypotonically swollen non-stimulated control cells resulted in a significant faster RVD (higher $\mathrm{Cl}^{-}$permeability) with a $34.3 \pm 1.02 \%$ recovery compared to $-0.102 \pm$ $1.24 \%$ (statistically not different from zero) seen in the CD3/CD28 activated T cells. Thus there was a significant decrease $(\mathrm{p}<0.05)$ in the $\mathrm{Cl}^{-}$permeability in stimulated $\mathrm{T}$ cells when comparing them to their non-activated counterparts.

\section{KARGER}




\section{Cellular Physiology Cell Physiol Biochem 2016;38:883-892

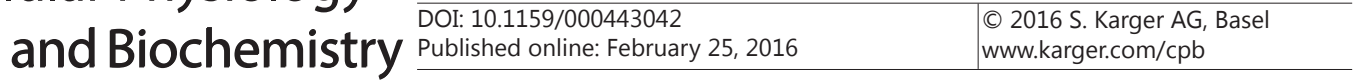 \\ Kirkegaard et al.: KCNK5 and T Cell Activation}

\section{Discussion}

In the current study we find that the activated human $\mathrm{T}$ cells enlarge upon activation which is a well described feature in the activated and proliferating T cells [28, 29]. There is a strong up-regulation of KCNK5 which is in agreement with earlier findings [8, 23]. The time profile described here shows an initial (after 2 and 4 hours of CD3/CD28 stimulation) and significant decrease in KCNK5 protein expression in activated T cells which correlates with a minimal not significant early shrinkage and decreased maximum swelling when comparing the activated T cells to non-activated control cells.

CD3/CD28 activated T cells not only get larger when measured in isotonic Ringer's solution they also swell significantly more when subjected to a hypotonic Ringer' solution as if they have an inhibited $\mathrm{KCl}$ efflux. Despite the up-regulation of the potent volume regulator KCNK5 we find the activated T cells to have an inhibited RVD performance upon cell swelling compared to the control cells. Since an up-regulation of KCNK5 protein expression and a decreased RVD might seem contradictory we speculate if the up-regulation occurs in order to facilitate proliferation. Proliferating cells are enlarged to keep daughter cells the same size as the parental cell a feature vital for successful proliferation, thus a strong RVD mechanism would be problematic for the activated $\mathrm{T}$ cell whose main objective is to increase in size and number to sufficient fight off a pathogenic intrusion. Cell swelling has been shown to facilitate proliferation in different cells [30-32]. The KCNK5 up-regulation will help insure a hyperpolarization of the cell membrane and thus a sustained $\mathrm{Ca}^{2+}$ influx vital for the longterm activation of the $\mathrm{T}$ cells keeping them activated in an antigen-independent manner [3337 this would facilitate optimal conditions for the $T$ cell expansion. Andronic et al. find the RVD performance in stimulated and non-stimulated $\mathrm{T}$ cells to be the same, an observation contradicting our findings [23], but Andronic et al. only measure the $20 \mathrm{~min}$. volume recovery and from their Fig. 2 we calculate the initial rate of volume recovery to be slower in stimulated cells compared to non-stimulated cell as found in the present study. Furthermore they use video microscopy to measure the volume a method quite different from our experimental set-up in which we measure the absolute cell volume of cells in suspension using a Coulter Counter. With respect to maximum swelling we and Deutch and Lee [38] find the stimulated cells to swell more than non-stimulated control cells an observation contradicting what was found by Andronic et al. [23]. We do not have an explanation for these apparent differences. It should be pointed out that the hypotonic and isotonic solutions used for cell volume measurements in the present study contain equal amount of electrolyte. Therefore there were no changes in the extracellular ion concentration during hypotonic treatment only in osmolarity. This is different from the condition used by Bobak et al. [18] and Andronic et al. [23] where hypotonic solutions also had a decreased ion concentration, the possible importance of this difference has not been tested.

Since the RVD in activated T cells was found to be inhibited despite the strong upregulation of KCNK5 protein we speculated whether the swelling-mediated $\mathrm{Cl}^{-}$permeability in activated T cells could be inhibited thereby setting a limit for the cells RVD capacity. We tested this and found that the $\mathrm{Cl}^{-}$permeability through the volume-sensitive anion channel VRAC indeed was inhibited in the activated T cells compared to control cells. This means that regardless of the increase in KCNK5 protein quantity the cells will not perform RVD as long as there is a functional down-regulation of VRAC since the $\mathrm{KCl}$ efflux during RVD is an electroneutral process. It should be noted that our results are in conflict with those published by Deutsch and Lee in 1988 [38] where it is shown how phytohemagglutinin activated human peripheral blood lymphocytes (PBL) respond to Gramicidin in a set-up similar to ours by decreasing cell volume, and it is thus speculated that $\mathrm{K}^{+}$is the rate limiting factor of RVD in activated T cells. A major difference seems to be that Deutsch and Lee are not adding Gramicidin until 30+ minutes after cell swelling whereas we add it immediately after cell swelling when the channels are maximally stimulated. We have previously shown in Ehrlich cells that the volume activated $\mathrm{Cl}^{-}$channels close before $15 \mathrm{~min}$. after swelling activation [27] and Sarkadi and co-workers show that it is also true in human lymphocytes 


\begin{tabular}{|c|c|c|}
\hline Cellular Physiol & Cell Physiol Biochem 2016;38:883-892 & \\
\hline and Biochemistry & $\begin{array}{l}\text { DoI: 10.1159/000443042 } \\
\text { Published online: February 25, } 2016\end{array}$ & $\begin{array}{l}\text { O } 2016 \text { S. Karger AG, Basel } \\
\text { www.karger.com/cpb }\end{array}$ \\
\hline
\end{tabular}

[39]. Another difference between our experiments and those presented by Deutsch and Lee is the fact that they used PBL's which contained T cells, B cells and monocytes whereas we use purified T cells.

The role of two pore-domain channels in T cells has been doubted by some $[1,3]$ our results contribute to the emerging evidence contradicting this doubt, thus in summary we suggest that the KCNK5 up-regulation detected in CD3/CD28 activated human T cells helps ensure a hyperpolarization of the membrane thus favoring a sustained $\mathrm{Ca}^{2+}$ influx and $\mathrm{T}$ cell activation. We further suggest that to keep the cells from loosing volume thereby supporting a strong proliferation the $\mathrm{Cl}^{-}$channel VRAC is functionally down-regulated.

\section{Acknowledgements}

The technical skills of Dorthe Nielsen (University of Copenhagen) and Pia Birn (Novo Nordisk) is gratefully acknowledged and appreciated. This work was supported by The Danish Council for Independent Research/Natural Sciences (grants 09-064182 and 10085373) and The Lundbeck Foundation, Denmark (J Nr R32-A3102).

\section{Disclosure Statement}

The authors declare that they have no conflict of interest.

\section{References}

1 Panyi G, Varga Z, Gáspár R: Ion channels and lymphocyte activation. Immunol Lett 2004;92:55-66.

2 Cahalan MD, Chandy KG: The functional network of ion channels in T lymphocytes. Immunol Rev 2009;231:59-87.

3 Varga Z, Hajdu P, Panyi G: Ion channels in T lymphocytes: An update on facts, mechanisms and therapeutic targeting in autoimmune diseases. Immunol Lett 2010;130:19-25.

$4 \quad$ Lewis RS: Calcium Signaling Mechanisms in T Lymphocytes. Annu Rev Immunol 2001;19:497-521.

5 Nam JH, Woo JE, Uhm DY, Kim SJ: Membrane-delimited Regulation of Novel Background K+ Channels by MgATP in Murine Immature B Cells. J Biol Chem 2004;279:20643-20654.

6 Zheng H, Nam JH, Pang B, Shin DH, Kim JS, Chun YS, Park JW, Bang H, Kim WK, Earm YE, Kim SJ: Identification of the large-conductance background $\mathrm{K}+$ channel in mouse B cells as TREK-2. Am J Physiol Cell Physiol 2009;297:C188-C197.

7 Meuth SG, Bittner S, Meuth P, Simon OJ, Budde T, Wiendl H: TWIK-related Acid-sensitive K+ Channel 1 (TASK1) and TASK3 Critically Influence T Lymphocyte Effector Functions. J Biol Chem 2008;283:1455914570.

8 Bittner S, Bobak N, Herrmann AM, Göbel K, Meuth P, Höhn KG, Stenner MP, Budde T, Wiendl H, Meuth SG: Upregulation of K2P5.1 potassium channels in multiple sclerosis. Ann Neurol 2010;68:58-69.

9 Bui AH, Wiley JS: Cation fluxes and volume regulation by human lymphocytes. J Cell Physiol 1981;108:4754.

10 Cheung RK, Grinstein S, Dosch H-M, Gelfand EW: Volume regulation by human lymphocytes: characterization of the ionic basis for regulatory volume decrease. J Cell Physiol 1982;112:189-196.

11 Cheung RK, Grinstein S, Gelfand EW: Volume regulation by human lymphocytes. Identification of differences between the two major lymphocyte subpopulations. J Clin Invest 1982;70:632-638.

12 Deutsch C, Slater L, Goldstein P: Volume regulation of human peripheral blood lymphocytes and stimulated proliferation of volume-adapted cells. Biochim Biophys Acta Mol Cell Res 1982;721:262-267.

13 Kirkegaard SS, Lambert IH, Gammeltoft S, Hoffmann EK: Activation of the TASK-2 channel after cell swelling is dependent on tyrosine phosphorylation. Am J Physiol Cell Physiol 2010;299:C844-C853.

14 Niemeyer MI, Cid LP, Barros LF, Sepúlveda FV: Modulation of the Two-pore Domain Acid-sensitive K+ Channel TASK-2 (KCNK5) by Changes in Cell Volume. J Biol Chem 2001;276:43166-43174.

15 Barriere H, Belfodil R, Rubera I, Tauc M, Lesage F, Poujeol C, Guy N, Barhanin J, Poujeol P: Role of TASK2 Potassium Channels Regarding Volume Regulation in Primary Cultures of Mouse Proximal Tubules. J Gen Physiol 2003;122:177-190. 


\section{Cellular Physiology Cell Physiol Biochem 2016;38:883-892 \begin{tabular}{l|l|l}
\hline DOI: 10.1159/000443042 & (C) 2016 S. Karger AG, Basel
\end{tabular} www.karger.com/cpb \\ Kirkegaard et al.: KCNK5 and T Cell Activation}

16 Barfield JP, Yeung CH, Cooper TG: Characterization of potassium channels involved in volume regulation of human spermatozoa. Mol Hum Reprod 2005;11:891-897.

17 Barfield JP, Yeung CH, Cooper TG: The Effects of Putative K+ Channel Blockers on Volume Regulation of Murine Spermatozoa. Biol Reprod 2005;72:1275-1281.

18 Bobak N, Bittner S, Andronic J, Hartmann S, ühlpfordt F, Schneider-Hohendorf T, Wolf K, Schmelter C, Göbel K, Meuth P, Zimmermann H, Döring F, Wischmeyer E, Budde T, Wiendl H, Meuth SG, Sukhorukov VL: Volume regulation of murine $\mathrm{T}$ lymphocytes relies on voltage-dependent and two-pore domain potassium channels. Biochim Biophys Acta 2011;1808:2036-2044.

19 Cid LP, Roa-Rojas HA, Niemeyer MI, González W, Araki M, Araki K, Sepúlveda FV: TASK-2: a K2P K+ channel with complex regulation and diverse physiological functions. Front Physiol 2013;4:1-9.

20 Lee SC, Price M, Prystowsky MB, Deutsch C: Volume response of quiescent and interleukin 2-stimulated T-lymphocytes to hypotonicity. Am J Physiol Cell Physiol 1988;254:C286-C296.

21 Cahalan MD, Lewis RS: Role of potassium and chloride channels in volume regulation by T lymphocytes. Soc Gen Physiol Ser 1988;43:281-301.

22 Schlichter LC, Sakellaropoulos G: Intracellular Ca2+ Signaling Induced by Osmotic Shock in Human T Lymphocytes. Exp Cell Res 1994;215:211-222.

23 Andronic J, Bobak N, Bittner S, Ehling P, Kleinschnitz C, Herrmann AM, Zimmermann H, Sauer M, Wiendl H, Budde T, Meuth SG, Sukhorukov VL: Identification of two-pore domain potassium channels as potent modulators of osmotic volume regulation in human T lymphocytes. Biochim Biophys Acta Biomembr 2013;1828:699-707.

24 Kirkegaard SS, Wulff T, Gammeltoft S, Hoffmann EK: KCNK5 is Functionally Down-Regulated Upon LongTerm Hypotonicity in Ehrlich Ascites Tumor Cells. Cell Physiol Biochem 2013;32:1238-1246.

25 Lundby C, Nordsborg N, Kusuhara K, Kristensen K, Neufer P, Pilegaard H: Gene expression in human skeletal muscle: alternative normalization method and effect of repeated biopsies. Eur J Appl Physiol 2005;95:351-360.

26 Pfaffl MW: A new mathematical model for relative quantification in real-time RT-PCR. Nucleic Acids Res 2001;29:2002-2007.

27 Hoffmann E, Lambert I, Ole Simonsen L: Separate, Ca2+-activated K+ and Cl- transport pathways in Ehrlich ascites tumor cells. J Membrain Biol 1986;91:227-244.

28 Zaffran Y, Destaing 0, Roux As, Ory Sp, Nheu T, Jurdic P, Rabourdin-Combe C, Astier AL: CD46/CD3 Costimulation Induces Morphological Changes of Human T Cells and Activation of Vav, Rac, and Extracellular Signal-Regulated Kinase Mitogen-Activated Protein Kinase. J Immunol 2001;167:6780-6785.

29 Petrzilka GE, Schroeder HE: Activation of human T-lymphocytes. Cell Tissue Res 1979;201:101-127.

30 Hoffmann EK, Lambert IH, Pedersen SF: Physiology of Cell Volume Regulation in Vertebrates. Physiol Rev 2009;89:193-277.

31 Klausen TK, Preisler S, Pedersen SF, Hoffmann EK: Monovalent ions control proliferation of Ehrlich Lettre ascites cells. Am J Physiol Cell Physiol 2010;299:C714-C725.

32 Madsen CP, Klausen TK, Fabian A, Hansen BJ, Pedersen SF, Hoffmann EK: On the role of TRPC1 in control of Ca2+ influx, cell volume, and cell cycle. Am J Physiol Cell Physiol 2012;303:C625-C634.

33 Weiss A, Imboden J, Shoback D, Stobo J: Role of T3 surface molecules in human T-cell activation: T3-dependent activation results in an increase in cytoplasmic free calcium. Proc Natl Acad Sci USA 1984;81:4169-4173.

34 Imboden JB, Weiss A, Stobo JD: The antigen receptor on a human T cell line initiates activation by increasing cytoplasmic free calcium. J Immunol 1985;134:663-665.

35 Crabtree GR: Contingent Genetic Regulatory Events in T Lymphocyte Activation. Science 1989;243:355361.

36 Goldsmith MA, Weiss A: Early signal transduction by the antigen receptor without commitment to T cell activation. Science 1988;240:1029-1031.

37 Negulescu PA, Shastri N, Cahalan MD: Intracellular calcium dependence of gene expression in single T lymphocytes. Proc Natl Acad Sci USA 1994;91:2873-2877.

38 Deutsch C, Lee SC: Cell volume regulation in lymphocytes. Renal Physiol Biochem 1988;11:260-276.

39 Sarkadi B, Mack E, Rothstein A: Ionic events during the volume response of human peripheral blood lymphocytes to hypotonic media. II. Volume- and time-dependent activation and inactivation of ion transport pathways. J Gen Physiol 1984;83:513-527. 